\title{
LIABILITY EKSISTENSI SAMPAH UNTUK KOMPARASI LINGKUNGAN
}

\section{Fuad Saiful Lutfi \\ Program Studi Arsitektur Fakultas Teknik Universitas Muhammadiah Surakarta Slfuad38@gmail.com}

\section{Fadhilla Tri Nugrahaini}

Program Studi Arsitektur Fakultas Teknik Universitas Muhammadiyah Surakarta ftn995@ums@ac.id

\begin{abstract}
ABSTRAK
Liability merupakan pertanggungjawaban dalam konteks ruang lingkup ekologi manusia. Masalah-masalah yang terjadi di masyarakat serta hubungan manusia, lingkungan, pola sosial dan budaya dapat dijadikan bahan pendukung untuk mengetahui hubungan antara makhluk hidup dan lingkungannya dalam pertanggungjawaban tersebut. Penelitian ini bertujuan untuk mengetahui gambaran pola perilaku melalui komparasi manusia dan lingkungan dalam isu tanggap lingkungan pada dua lokasi penelitian. Lokasi pertama adalah Kelurahan Plesungan, Mojosongo dengan radius kurang dari satu kilo dari TPA Putri Cempo. Lokasi kedua adalah Kampung Kitiran, Yosoroto, Purwosari, Laweyan. Kedua lokasi tersebut menjadi objek penelitian untuk dibandingkan terkait pola perilaku masyarakat dalam rangka mengetahu pertanggungjawaban manusia terhadap lingkungan dalam isu eksistensi sampah. Selain itu, beberapa strategi perlu dilakukan untuk mencapai kehidupan berkelanjutan melalui pendekatan ekologi terkait behaviorenvironment. Penelitian ini menggunakan metode kualitatif dimana peneliti mengawasi, mengamati dan mencatat serta terlibat dalam kegiatan masyarakat di wilayah objek pengamatan. Hasil yang diperoleh berupa pemaparan tentang karateristik dari kedua wilayah, arahan dan gambaran pertanggungjawaban utama masyarakat pada keberadaan sampah dan lingkungannya yaitu keberhasilan dalam memakmurkan kehidupannya yakni menghasilkan lingkungan yang baik, dimana lokasi pertama disarankan mencontoh lokasi kedua terkait perilaku dalam tanggap sampah dan lingkungannya seperti menciptakan penghijauan, membentuk komunitas, relasi hubungan sosial, dan strategi untuk mengatasi krisis seputar lingkungan.
\end{abstract}

KATA KUNCI: manusia, pola perilaku, pertanggungjawaban, sampah

\section{PENDAHULUAN}

\section{Latar Belakang}

Setiap manusia dalam melakukan kegiatannya akan selalu membutuhkan orang lain dan wadah untuk melakukan kegiatannya (Purwantiasning, 2017). Wadah inilah yang kemudian dikenal sebagai ruang berinteraksi, baik secara individu maupun secara berkelompok. Pola perilaku manusia dalam sebuah komunitas bermasyarakat adalah hasil dari interaksi keberadaan manusia dan lingkungannya. Ketika manusia menghargai lingkungan maka lingkungan akan menghargai kembali posisi manusia, sehingga dengan begitu tumbuh interaksi antara manusia, alam dan Sang Pencipta.

Gambaran perilaku manusia dalam menanggapi isu terkait lingkungan dan karakter behaviour (tingkah laku) perlu dilakukan untuk mengetahui eksistensi yang mengarah kepada pertanggungjawaban lingkungan. Kenyataannya banyak manusia terutama masyarakat Kota Solo yang menganggap serius pentingnya kebersihan lingkungan, selain itu kesadaran manusia dalam menumbuhkan inovasi pada produk buangan rumah tangga sudah mulai diperhatikan seperti contoh kecilnya yaitu menyediakan tempat sampah dan menanam penghijauan di setiap rumah. Begitu pula kegiatan sosialisasi kebersihan lingkungan pada setiap masyarakat. Hal ini penting untuk menunjang sumber daya manusia serta integrasi manusia dan alam, seperti penanaman pohon, menciptakan ruang terbuka hijau dan mengatur pola perilaku dalam membuang produk buangan. Kegiatan tersebut merupakan keberhasilan dalam menciptakan kehidupan yang berkelanjutan.

Dalam pengkajian penelitian ini tidak terlepas dari pembahasan mengenai psikologi, lingkungan, dan manusia. Veitch dan Arkkelin (1995) menjelaskan definisi psikologi lingkungan, yang merupakan disiplin ilmu perilaku bersifat multidipliner yang memfokuskan ketertarikan antara sekitar. Seiring dengan perkembangan zaman dan tingkat populasi kehidupan manusia terus bertambah sehingga memunculkan produk-produk buangan yang memicu dampak terkait kehidupan yang berkelanjutan terutama menanggapi isu pemanasan global. Pemanasan global merupakan isu terbesar masalah lingkungan yang mengancam keberlangsungan kehidupan serta tempat tinggalnya. 
Istiqomah Wibowo (2009) dalam penelitian "Pola Perilaku Kebersihan: Studi Psikologi Lingkungan Tentang Penanggulangan Sampah Perkotaan" menyebutkan, bahwa objek (S) akan menimbukan respon/perilaku (R). Perbuatan seseorang dalam lingkungan fisik tertentu, merupakan proses yang saling terkait dan saling pengaruh-mempengaruhi antara 1) (O) sebagai pelaku, 2) wujud perilaku/perbuatan itu sendiri (R), dan 3) lingkungan. Pada hakekatnya, makna ini ditentukan pula oleh niat atau maksud (O). Transaksi antara (O) dan (R) serta (S) dalam suatu lingkungan yang berlangsung terus menerus dapat menjelaskan mengapa terdapat tindakan-tindakan khusus pada tempat dan waktu khusus pula.

Kajian lebih lanjut terkait mencari kebenaran antara teori dan lapangan studi, psikologi serta ekologi manusia perlu dilakukan komparasi. Karakteristik pola perilaku dan tipologi tapak terkait objek penelitian, penulis mencoba membandingkan antara studi kasus langsung di lapangan dengan hasil penelitian dalam jurnal penelitian.

Penelitian ini mengambil 2 lokasi sebagai objek penelitian. Objek pertama yaitu Kelurahan Plesungan, Mojosongo. Daerah tersebut menarik untuk dijadikan objek penelitian karena letak desa yang berada kurang dari radius satu kilometer dari Tempat Pembuangan Akhir (TPA) Putri Cempo. Lokasi kedua adalah Kampung Kitiran, Yosoroto, Purwosari. Kampung Kitiran adalah salah satu kampung dengan tingkat populasi manusia aktif, terlebih wilayah tersebut sangat jauh dengan lokasi TPA di kota Solo yang seharusnya minim akan bahan mentah untuk dijadikan produk baru yang bermanfaat dan minimnya lahan untuk menciptakan ruang terbuka hijau. Kampung Kitiran adalah salah satu inovasi kampung dengan kesadaran gerakan peduli lingkungan dan menciptakan lingkungan yang berkelanjutan.

Melakukan komparasi dengan mengutip pendekatan ekologi-psikologi lingkungan terlepas dari status pekerjaan masyarakat di wilayah tersebut untuk mengetahui poin-poin, menganalisis hubungan sebabakibat ketertarikan manusia dan lingkungan yang diteliti dalam keberhasilan atau tidaknya warga dalam menanggapi isu sampah pada dua lokasi tersebut. Data yang diperoleh bukan bersifat statistic, melainkan deskripsi mengenai gambaran/polapola/perilaku manusia yang memperlakukan dan salah satunya produk/hasil dampak dari sampah untuk eksisting tempat tinggalnya dengan adanya suatu alasan serta sebab-akibat sebagai bahan penunjang untuk menjadikan lingkungan yang berkelanjutan.

Hal tersebut perlu dilakukan untuk memperoleh data dan gambaran mengenai pertanggungjawaban terhadap lingkungan dan faktor yang menyebabkan manusia tertarik atau tidaknya dalam menciptakan gerakan sampah yang berhasil dan sebaliknya. Selain itu gambaran tersebut dapat memberikan arahan dan strategi terkait luaran aspek arsitektur yang dapat direncanakan untuk menciptakan kehidupan berkelanjutan.

Berdasarkan latar belakang tersebut, maka menarik untuk dipelajari:

1. Bagaimana faktor dan pola pergerakan warga terkait pengaruh kesadaran isu eksistensi sampah?

2. Bagaimana proses menuju lingkungan yang sehat berdasar pertanggungjawaban manusia pada eksistensi sampah yang semakin berkembang?

3. Bagaimana luaran pada aspek arsitektur mengenai pertanggungjawaban isu sampah?

Dalam menjawab rumusan masalah tersebut, perlunya dilakukan pendekatan ekologi manusia dan masalah lingkungan. Secara umum ekologi dapat diartikan sebagai hubungan antara organisme dan habitatnya, atau ilmu yang mempelajari tentang hubungan antara makhluk hidup dengan lingkungannya (Sukmana (2003). Dalam lingkup ekologi manusia, terdapat empat komponen yang saling berpengaruh yaitu:

1. Komponen Manusia (penduduk)

2. Komponen Daya Dukung Alam (lingkungan)

3. Komponen Ilmu Pengetahuan dan Teknologi (IPTEK)

4. Komponen Organisasi

Empat komponen tersebut saling bergantung dan mempengaruhi satu sama lainnya. Pengolahan kekayaan alam demi memenuhi kehidupan manusia juga tergantung pada daya dukung alam (lingkungan) yang ada. Selain itu daya dukung ilmu pengetahuan yang menyebabkan penduduk mempunyai sistem organisasi yang baik juga sangat penting. Hubungan timbal balik antara komponen alam dan sosial yang mencerminkan komparasi daerah maju dan terbelakang. Daerah terbelakang komponen yang berpengaruh adalah komponen alam, sedangkan daerah maju komponen yang paling berperan adalah komponen sosial. Penelitian ini diharapkan dapat memberikan manfaat yaitu untuk mengetahui gambaran pertanggungjawaban perilaku terhadap eksistensi sampah untuk komparasi lingkungan tempat tinggalnya sebagai studi pembelajaran dalam memunculkan gerakan sumber daya manusia dan hubungan timbal balik dalam ruang lingkup ekologi manusia yang berangkat dari kondisi eksistingmasyarakat yakni kesadaran dan pembelajaran terkait arsitektur berkelanjutan.

\section{METODE PENELITIAN}

Penelitian ini menggunakan pendekatan kualitatif deskripsi yaitu penelitian dengan menggambarkan 
atau melukiskan fakta-fakta atau keadaan ataupun gejala yang tampak dalam objek penelitian. Penetapan penelitian ditentukan secara purposive atau berdasarkan pertimbangan-pertimbangan dan tujuan penelitian. Lokasi penelitian ini ditentukan dengan adanya suatu pertimbangan bahan komparasi terkait pola perilaku dan sebab-akibat. Penulis memfokuskan di dua lokasi yaitu Kelurahan Plesungan, Mojosongo (TPA Putri Cempo) dan Kampung Kitiran Josoroto, Laweyan.

\section{Tahap pengumpulan data}

Tahapan pengumpulan data terdiri atas 3 tahap:

1. Tahap pertama: Tahap pertama adalah tahap mencari tinjauan literatur. Literatur berupa buku, jurnal dan sumber dari internet terkait pembahasan psikologi lingkungan dan pembahasan mengenai ekologi lingkungan dan manusia.

2. Tahap kedua: Tahap kedua adalah pengamatan dan wawancara. Pengamatan difokuskan pada situasi dan kondisi eksisting desa serta perilaku warga yang berada di wilayah pengamatan. Pengamatan ditindaklanjuti dengan wawancara dengan sasaran Ketua RW, warga setempat dan orang-orang yang berpengaruh seperti penggagas gerakan terkait sampah di wilayah pengamatan.

3. Tahap ketiga: Tahap ketiga adalah tahap pengumpulan data, dari hasil observasi, wawancara dan memberikan kuisioner kepada narasumber, serta ikut berkontribusi dalam kegiatan di wilayah pengamatan. Secara deskriptif kualitatif, data diuraikan atau mendiskripsikan apa yang terjadi di objek pengamatan dan melakukan komparasi terkait pola perilaku manusia, karateristik fisik manusia, dan luaran terkait produk atau gambaran yang mengarah pada topik pembahasan penelitian.

Tahap akhir dilanjutkan dengan memberikan kesimpulan dan menghubungkan hasil lapangan dengan teori-teori yang didapat dari sumber buku yang dibaca sebelum melakukan penelitian. Hasil tersebut akan dapat disimpulkan pertanggungjawaban masyarakat dalam lingkup eksistensi sampah yang berkembang di objek atau lokasi penelitian.

\section{HASIL PENELITIAN}

Isu yang berkembang terkait pertanggungjawaban lingkungan, berangkat dari segi mikro yaitu wilayah pemukiman. Analisis lanjutan menyebar ke wilayah messo dan makro pada tapak lokasi pengamatan. Produk luaran mengenai arsitektur yang perlu ditambahkan di wilayah objek pengamatan untuk lebih mendiskripsikan keadaan sebenarnya.

Menurut model yang dilakukan, pelaku yang bertindak sebagai objek utama (manusia) ditentukan oleh faktor-faktor internal. Hal-hal yang mendasari pelaku melakukan tanggap lingkungan adalah dipengaruhi oleh faktor internal dan eksternal. Faktorfaktor internal meliputi kesadaran, hasrat, dan sikap. Sedangkan, faktor eksternal meliputi situasi atau manusia, yang akan terbentuk sendiri melalui proses pembelajaran dalam konteks lingkungan tempat tinggalnya.

Secara garis besar pada dua lokasi pengamatan sudah terdapat beberapa strategi guna mencapai kehidupan berkelanjutan, namun untuk menuju strategi yang benar dibutuhkan indikator-indikator terbentuknya rutinitas sikap yang kritis terhadap tanggap lingkungan. Berikut akan dipaparkan pokok kajian indikator dalam menanggapi eksistensi sampah sebagai sumber indicator pada tabel 1 .

Tabel 1. Indikator Sumber dan Konteks Setting

\begin{tabular}{ll}
\hline Pokok Kajian Indikator & $\begin{array}{c}\text { Setting-Perilaku (S- } \\
\text { P) Kondisi Setting }\end{array}$ \\
\hline 1. Sumber setting & \\
- $\quad$ Manusia (penduduk) & \\
- $\quad$ Benda/ objek & \\
- Informasi & Temuan data \\
\hline 2. Konteks setting & \\
- Hubungan/jaringan & \\
- Kondisi sosial ekonomi & \\
- Gaya Hidup & \\
- Keadaan geografik & \\
\hline
\end{tabular}

Berdasarkan pemaparan terkait tinjauan literatur mengenai ekologi-psikologi lingkungan, hal tersebut digambarkan menjadi tabel indikator pengelompokan pola setting-perilaku (S-P) pada dua objek pengamatan. Dimana setting-perilaku berdasar tinjauan perilaku mengenai pertanggungjawaban lingkungan yang mencakup dari berbagai aspek bentuk-tindakan serta relasi-jaringan pada aktivitas masyarakat di kedua lokasi objek pengamatan dan kemudian menghasilkan temuan-temuan yang berangkat dari sebab-akibat.

\section{Penentuan Lokasi Pengamatan}

Penentuan lokasi pengamatan berdasar beberapa kriteria atau pertimbangan, sebagai berikut:

1. Jangkauan radius dari pusat TPA

Mengetahui bagaimana eksistensi sampah di wilayah yang dekat dengan sumber sampah, mengetahui kehidupan mereka dan mengetahui pola perilaku manusia apakah manusia pada tapak tersebut menghasilkan produk luaran oleh lokasi pertama yaitu Kelurahan Plesungan Mojosongo dalam segi perbaikan sumber daya ataukah justru lokasi yang jauh dari TPA yaitu kampung Kitiran Yosoroto yang ditinjau dari segi 
aksesibilitas dan pola perilakunya menghasilkan banyak produk luaran dan strateginya dengan potensi masyarakat yang bertanggungjawab

2. Pengorganisasian dan jaringan luar

Menelaah pentingnya jaringan luar untuk membantu menciptakan strategi dan kesadaran terkait lingkungan yang berkelanjutan.

3. Kondisi permukiman

Mengkaji eksisting permukiman berdasarkan observasi lapangan.

4. Kualitas hidup berkelanjutan

Pengetahuan mengenai lingkungan hidup oleh masyarakat hingga definisi pencapaian kehidupan yang makmur.

Berikut akan dipaparkan gambaran overviews pada kedua objek lokasi pengamatan:

\section{Lokasi 1: Kelurahan Plesungan, Mojosongo.}

Karateristik tipologi permukiman di lokasi 1 cenderung tidak padat dan masih banyak lahan kosong. Lokasi 1 terletak kurang dari radius satu kilometer dari TPA Putri Cempo yang tentunya menarik untuk diteliti. Dari data yang disampaikan melalui kuisioner yang ditanyakan langsung kepada ketua RW 1 didapatkan hasil bahwa kondisi manusia yang tinggal di radius kurang dari satu kilometer sangat perlu bimbingan dalam kegiatan rutin. Salah satunya penyuluhan tentang kesehatan.

Informasi yang lain, berdasarkan data yang disampaikan oleh salah satu warga (Sumino, ketua RW 1) bahwa warga disekitar TPA mengaku jarang sakit yang disebabkan oleh sampah. Problematika serius pada lokasi disebutkan salah satunya isu pernah terjadi kebakaran di sumber TPA yang karena kemarau panjang, yang mengakibatkan asap terbawa oleh udara bergerak ke permukiman. Saat itu anak-anak terpaksa diungsikan di tempat hunian sementara. Sosisalisi dari Dinas Kesehatan terkait pemberian arahan tentang lingkungan sehat telah dilakukan. Warga kurang antusias, masyarakat percaya bahwa keyakinan kepada Tuhan YME dan faktor makanan yang menjadi pemicu warga jarang terkena sakit.

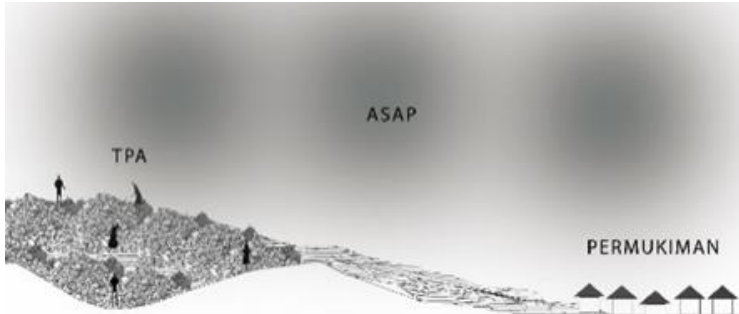

Gambar 1. Illustrasi kondisi eksisting permukiman 1 (sumber: Analisis Penulis, 2019)

Dampak yang ditimbulkan dari lingkungan tersebut adalah asap dan bau. Apabila terjadi kebakaran, warga langsung berinisiatif mengungsikan anak-anak mereka dan memindahkan sementara di tempat yang jauh dari radius TPA. Hal tersebut disebabkan asap dari sampah yang dapat mengganggu sistem pernafasan. Selain itu kurangnya pepohonan atau tanaman sebagai RTH dan barrier antara TPA dan permukiman.

Masyarakat kurang bisa untuk memanfaatkan potensi alam untuk kelangsungan hidup dan terlebih mereka mempunyai sumber daya alam yang melimpah. Pola perilaku yang ditunjukkan oleh warga Plesungan yang setiap hari mencari sampah langsung dari TPA. Sampah dibawa ke rumah untuk ditabung sebagai celengan jika sewaktu-waktu membutuhkan uang, sampah akan diangkut dan dijual. Hal tersebut dirasa kurang menunjukkan esensi kehidupan dan lingkungan yang berkualitas baik. Namun hal tersebut sudah menjadi kebiasaan turun temurun dan bahkan di tiap-tiap rumah melakukan hal yang sama.

Pola perilaku yang terbiasa terhadap lingkungan sampah mengakibatkan kurangnya kesadaran dalam mendorong gerakan kehidupan berkelanjutan. Berdasarkan data yang diperoleh, strategi-strategi yang pernah diusulkan oleh ketua RW dengan maksud memperbaiki sumber daya warganya yang lebih baik, terlihat pada tabel 2 .

Tabel 2. Strategi dan Respon Warga

\begin{tabular}{|c|c|}
\hline Strategi & Respon/luaran \\
\hline 1. Bank sampah & berjalan \\
\hline Strategi yang & dikarenakan \\
\hline $\begin{array}{l}\text { diusulkan oleh ketua RT } \\
\text { mengenai bank sampah }\end{array}$ & $\begin{array}{l}\text { tidak sabar membuat } \\
\text { potongan plastik }\end{array}$ \\
\hline $\begin{array}{lr}\text { yaitu warga } & \text { secara rutin } \\
\text { menabung } & \text { potongan }\end{array}$ & $\begin{array}{l}\text { kedalam botol dan } \\
\text { masih menuggu lama }\end{array}$ \\
\hline plastik yang & untuk \\
\hline $\begin{array}{l}\text { disimpan kedalam botol } \\
\text { plastic, kemudian hal } \\
\text { tersebut dijadikan tabungan } \\
\text { oleh warga untuk ditukar ke }\end{array}$ & $\begin{array}{l}\text { pengelolaannya. Hal } \\
\text { tersebut dianggap } \\
\text { warga kurang efisien } \\
\text { mengingat waktu. }\end{array}$ \\
\hline
\end{tabular}

bank sampah dengan diberikan buku tabungan kemudian dicatat identitas dan uang diambil pada bulan Ramadhan.

\section{Pengelompokan}

keanggotaan Pemulung

Stategi dengan pembuatan KTA (Kartu Tanda Anggota) pemulung, kemudian dilakukannya arisan atau kumpulan.

Diadakannya kas rutin dan kemudian uang dari kas dikembangkan untuk strategi yang lain

\begin{tabular}{rlr}
\hline 3. Pengembangan Uang Kas & Terlaksana, & untuk \\
Strategi pengembangan uas & kegiatan & yang \\
Kas untuk dikembangkan & memerlukan & dana \\
sebagai pinjaman ke warga, & tambahan. & \\
contohnya warga & & \\
\hline
\end{tabular}




\begin{tabular}{|c|c|}
\hline Strategi & Respon/luaran \\
\hline $\begin{array}{l}\text { meminjam 100rb dan } \\
\text { kembali 120rb }\end{array}$ & \\
\hline $\begin{array}{l}\text { 4. Penanaman tanaman } \\
\text { apotik hidup } \\
\text { Upaya warga untuk } \\
\text { menanam tanaman apotik } \\
\text { hidup dengan } \\
\text { memanfaatkan sisa teh } \\
\text { sebagai media tanam. }\end{array}$ & $\begin{array}{l}\text { Terlaksana, akan tetapi } \\
\text { baru di beberapa } \\
\text { rumah saja dan perlu } \\
\text { diadakan sosialisasi } \\
\text { lebih lanjut untuk } \\
\text { apotik hidup. }\end{array}$ \\
\hline $\begin{array}{l}\text { 5. Pemanfaatan RTH } \\
\text { Tujuan utama penanaman } \\
\text { pohon adalah sebagai } \\
\text { barrier antara TPA dan } \\
\text { permukiman, tujuannya } \\
\text { untuk mencegah asap dan } \\
\text { memulai menciptakan } \\
\text { lingkungan yang asri }\end{array}$ & $\begin{array}{lr}\text { Belum } & \text { berjalan, } \\
\text { mengingat } & \text { warga } \\
\text { disibukkan dengan } & \text { pekerjaan mereka } \\
\text { memilah sampah, akan } & \\
\text { tetapi rencana } & \text { pengelolaan } \\
\text { lingkungan } & \\
\text { sebenarnya sudah ada. }\end{array}$ \\
\hline
\end{tabular}

Hal yang juga perlu disoroti terkait pertanggungjawaban ekologi dari permukiman ini adalah terdapat satu ruang publik yang cukup unik bertuliskan tajuk "Taman Sehat". Ruang publik yang disediakan berlokasi di samping TPA dan bertujuan untuk sarana berkumpul. Ruang public ini merupakan salah satu strategi menuju perkampungan yang sehat. Namun, pertanggungjawaban untuk taman tersebut seolah tidak terlihat dan tanah yang mulai mengering. Situasi "Taman Sehat" terlihat dalam gambar 2.

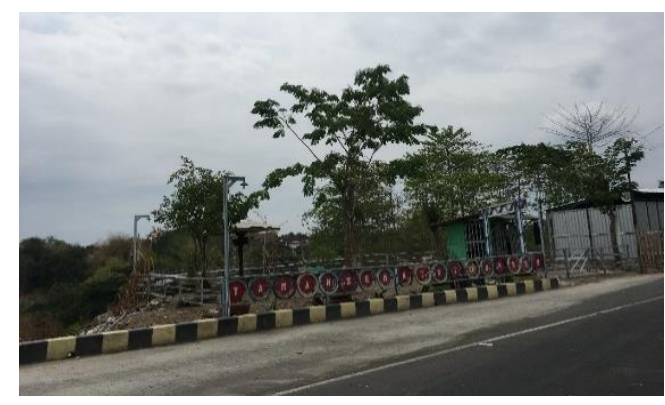

Gambar 2. Taman Sehat TPA Putri Cempo

(sumber: Analisis Penulis, 2019)

\section{Lokasi II: Kampung Kitiran, Yosoroto, Laweyan}

Kampung ini lahir dari keprihatinan bersama, kemudian tercetus pemikiran bagaimana menjadikan sebuah kampung yang dinamis. Dari ide tersebut lalu muncul inovasi yang dinilai baik untuk kehidupan masyarakat Kampung Kitiran. Berdasarkan wawancara kepada Ibu Denok (penggagas Kampung Kitiran) untuk membuat kampung ini benar benar bergerak dibutuhkan seluruh komitmen dari seluruh warga yang tinggal di kampung ini. Sehingga untuk branding (mengecap/menandai) dari kampung ini, dibuatlah kitiran (bahasa Jawa dari kincir yang memiliki filosofi berputar terus). Tujuan dari kampung ini adalah untuk menghidupkan mental baru dalam hal pengelolaan sampah dan memperbaiki sumber daya.

Cara pelaksanaan tujuan ini adalah dengan menempelkan poster alur pembuangan sampah yang ditempel di setiap pintu depan rumah warga. Sehingga warga ketika hendak masuk-keluar dari rumah akan selalu mengingat bagaimana cara mengelola sampah yang benar. Hal ini cukup efisien untuk menghidupkan mental baru dalam pengelolaan sampah dengan hal itu kemudian warga tersebut mengelola sampah mereka sendiri di dalam rumah. Memisahkan sampah mereka sendiri dari an-organik, organik, dan sampah lainnya, seperti sampah sayur sayuran sisa masakan disendirikan, botol plastik disendirikan, kardus pun demikian.

Tindakan yang mengarah pada perbaikan sumber daya manusia yang lebih baik umumnya ditampilkan oleh setiap rumah dengan memilah berbagai sampah. Kemudian secara rutin setiap minggu ke-2 dan ke-4 warga menjualnya di bank sampah. Berbeda dari komparasi lokasi pertama, pola kesadaran pada masyarakat Kampung Kitiran sudah mulai muncul pada 3 tahun terakhir, berawal dari keprihatinan tersebut. Hal ini lebih diperkuat lagi dengan kerjasama bersama Kantor Pegadaian untuk permasalahan tabungan bank sampah. Ada 2 tipe tabungan yaitu tabungan bank sampah kampung dan tabungan emas pegadaian, dimana tabungan emas ini nantinya dapat ditukar dengan emas. Strategi yang dikembangkan dan respon yang diberikan masyarakat terlihat dalam tabel 3.

Table 3. Strategi Dan Respon Luaran

\begin{tabular}{|c|c|}
\hline Strategi & Respon/luaran \\
\hline $\begin{array}{l}\text { 1. Bank Sampah } \\
\text { Strategi kerjasama antara } \\
\text { masyarakat dan institusi luar } \\
\text { ialah tabungan emas, yang } \\
\text { dikoordinir berbagai jenis } \\
\text { pemilihan berbai kemudian } \\
\text { sampah kepada bank } \\
\text { disetorkan kepalui } \\
\text { sampah setiap minggu ke-2 } \\
\text { dan minggu ke-4. } \\
\text { Manfaatnya warga dapat } \\
\text { menabung berupa uang dan } \\
\text { emas di kedua jenis } \\
\text { tabungan, yaitu tabungan } \\
\text { bank sampah dan tabungan } \\
\text { emas. Hal tersebut jelas } \\
\text { strategi memperbaiki } \\
\text { sumber daya manusia } \\
\text { masyarakat di Kampung } \\
\text { Kitiran }\end{array}$ & 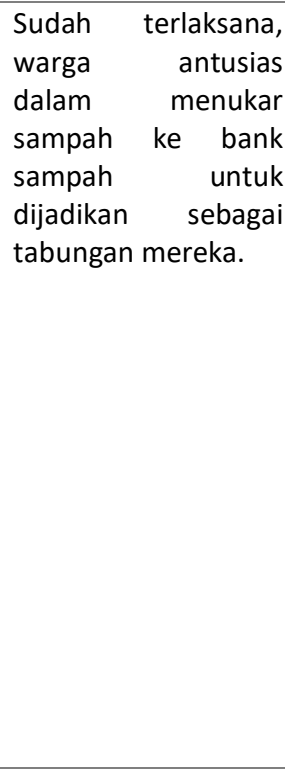 \\
\hline $\begin{array}{l}\text { 2. Sosialisasi dan rapat rutin } \\
\text { Selain membahas alur dan } \\
\text { visi kedepan, warga } \\
\text { mengadakan rapat rutin }\end{array}$ & $\begin{array}{l}\text { Terlaksana, rapat } \\
\text { tersebut membahas } \\
\text { strategi pengelolaan } \\
\text { dan hal yang perlu }\end{array}$ \\
\hline
\end{tabular}




\begin{tabular}{|c|c|}
\hline Strategi & Respon/luaran \\
\hline $\begin{array}{l}\text { untuk memperkuat } \\
\text { silaturahmi dan rasa sosial. }\end{array}$ & $\begin{array}{lr}\text { dilakukan } & \text { oleh } \\
\text { masyarakat } & \\
\text { Kampung } & \text { Kitiran } \\
\text { dalam menciptakan } \\
\text { kampung yang } \\
\text { dinamis }\end{array}$ \\
\hline $\begin{array}{l}\text { 3. Tim kerja pengelolaan } \\
\text { sampah } \\
\text { Terdapat } 7 \text { tim kerja dalam } \\
\text { pengelolaan sampah di } \\
\text { Kampung Kitiran, hal tesebut } \\
\text { bertujuan untuk } \\
\text { mempermudah dalam } \\
\text { mengkoordinir alur sampah. } \\
\text { Tim terbagi masing-masing } \\
\text { jobdesk mulai dari tim } \\
\text { pemilahan,tim kompos } \\
\text { sampai ke tim maintenance. }\end{array}$ & $\begin{array}{lr}\text { Terlaksana, } & \text { hal } \\
\text { tersebut } & \text { juga } \\
\text { menambah } & \\
\text { perekonomian } & \text { dari } \\
\text { masing-masing } & \text { tim } \\
\text { kerja. } & \end{array}$ \\
\hline $\begin{array}{l}\text { 4. Paket wisata } \\
\text { Memberikan edukasi dengan } \\
\text { menciptakan paket wisata } \\
\text { dengan tujuan memperbaiki } \\
\text { sumber daya dan mem- } \\
\text { branding kampung agar lebih } \\
\text { dikenal orang dan } \\
\text { memberikan output/contoh } \\
\text { terkait perilaku warganya } \\
\text { dalam mengelola Kampung } \\
\text { Kitiran }\end{array}$ & $\begin{array}{lr}\text { Terlaksana, } & \text { ada } \\
\text { beberapa instansi/ } \\
\text { individu yang datang } \\
\text { dan belajar terkait } \\
\text { pola } & \text { perilaku } \\
\text { warganya dalam } \\
\text { menciptakan } \\
\begin{array}{lr}\text { kampung } \\
\text { dinamis. yang }\end{array}\end{array}$ \\
\hline $\begin{array}{l}\text { 5. Apotik Hidup } \\
\text { Wajib bagi setiap rumah } \\
\text { menanam apotik hidup, jika } \\
\text { satu tanaman mati maka } \\
\text { kebijakan dari warganya } \\
\text { harus membayar denda } \\
\text { sebesar Rp30.000,-. }\end{array}$ & $\begin{array}{l}\text { Sudah terlaksana. } \\
\text { Hal tersebut } \\
\text { merupakan strategi } \\
\text { penanganan first aid } \\
\text { bagi masyarakatnya. }\end{array}$ \\
\hline
\end{tabular}

Setelah pemaparan kedua strategi beserta gambaran pola warga dalam menanggapi isu sampah dan pertanggungjawabannya, terlihat wilayah yang perlu adanya arahan atau sosialisasi beserta informasi terapan kerja adalah lokasi pertama yaitu Kelurahan Plesungan, Mojosongo. Tindakan-tindakan sadar lingkungan dan kebersihan perlu dilakukan oleh para pelaku yang cenderung memerlukan komunitas untuk bergerak secara bersama. Salah satunya memanfaatkan dan mendukung gerakan sehat seperti menghidupkan kembali ruang publik dan pemberdayaan ruang terbuka hijau. Manajemen pengelolaan sampah juga diperbaiki sebagai sarana meminimalisir dampak buruk terkait lingkungan pada lokasi 1. Pada lokasi 2 cukup terkondisi karena suatu keinginan bersama dan umumnya ditampilkan dengan sosialisasi atau gerak secara fisik, hal tersebut sebagai contoh gambaran simbiosis mutualisme dari manusia dan alam. Analisis perilaku pengelolaan sampah dalam lingkar sequence. Kajian terhadap hasil pengamatan di kedua lokasi diperoleh gambaran tentang tindakan masyarakat permukiman terhadap eksistensi sampah yang merupakan sebuah proses yang digambarkan melalui sequence pengelolaan:

a) Sequence pemilihan, berbagai kegiatan masyarakat dalam tindakan pemilihan sampah rumah tangga atau TPA atau barang-barang sisa yang sudah tidak diperlukan lagi.

b) Sequence buang, tindakan menyingkirkan sampah dari objek utama yaitu pelaku.

c) Sequence kumpul, pengelompokan atau mengumpulkan sampah kedalam satu wadah atau tempat sampah.

d) Sequence angkut, tindakan memindahkan sampah menggunakan gerobak atau mobil pickup.

e) Sequence jual, rangkaian tindakan menukar atau menjual kepada bank sampah atau pengepul sampah.

f) Sequence olah, rangkaian me-recycle atau membuat produk inovasi baru yang bermanfaat menggunkan bahan sisa dari sampah dan kemudian diolah dan dijual.

Masalah-masalah disekitar wilayah pengamatan masih kompleks dan berlangsung dalam konteks wilayah permukiman pedesaan. Sehingga perlu diketahui bahwa aktivitas dan gerakan sosial menyangkut dari semua pihak dan terjadi dalam unsur yang sama. Hanya saja kesadaran tiap individu berbeda-beda, hal tersebut dapat diasumsikan bahwa unsur pemegang pertanggungjawaban tertinggi terjadi pada individu dalam menentukan pola perilaku tanggap sampah di kawasan penelitian. Operasional pengelolaan dapat dibagi berdasar sequence. Gambaran pola pada lokasi 1 dan lokasi 2 tampilkan pada gambar 3 .

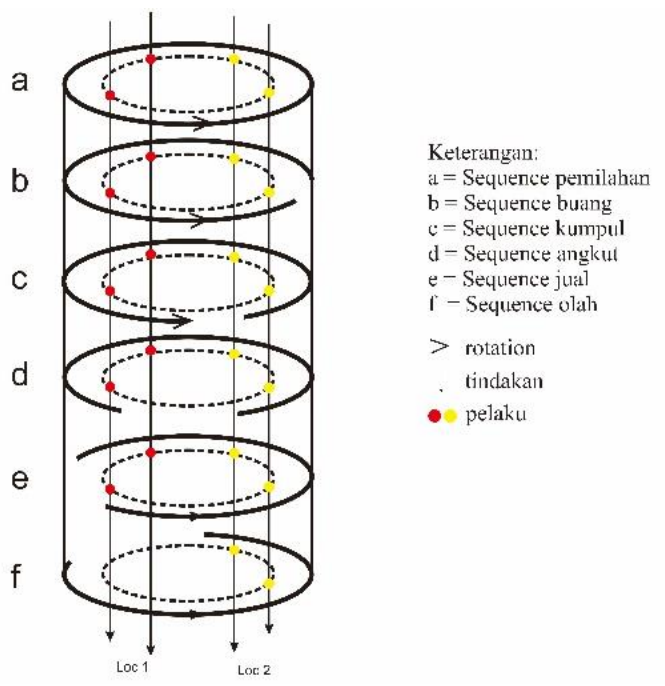

Gambar 3. Illustrasi Sequence Pengelolaan (sumber: Analisis Penulis,2019) 
Tindakan yang mendukung keberlanjutan sumber daya terlihat pada lokasi 2 yaitu Kampung Kitiran. Siklus sampah meneruskan ke sequence olah untuk menambah perekonomian dan pemanfaatan dari eksistensi sampah serta mendukung pola gerak berkelanjutan dengan pelaku yang sama.

\section{PEMBAHASAN}

Seperti yang sudah diuraikan sebelumya, terkait hasil studi terhadap pemahaman tentang cara mempertanggungjawabkan lingkungan. Ruang lingkup ekologi manusia merupakan dasar dari pembentukan karakter dari setiap individu. Esensi terhadap pengelolaan sampah dan perbaikan lingkungan sekitar jelas perlu dilakukan untuk meminimalisir dampak buruk yang ditimbulkan oleh lingkungan terhadap eksisting tempat tinggalnya, wilayah yang jauh dari TPA bukan berarti jauh terhindar dari penyakit yang disebabkan karena sampah namun kembali lagi setting-perilaku yang mampu mengubah pola kehidupan menjadi lebih baik sekalipun pada wilayah yang kurang dari radius satu kilo dari TPA. Pemaparan komparsi setting-perilaku terhadap kondisi lingkungan dikedua wilayah dan esensi pertanggungjawabannya tertuang dalam tabel 4 .

Table 4. Komparasi Lokasi Berdasar Sumber Dan Konteks Setting

\begin{tabular}{|c|c|c|}
\hline $\begin{array}{l}\text { Sumber } \\
\text { Setting }\end{array}$ & Lokasi I & Lokasi II \\
\hline \multirow[t]{2}{*}{ Manusia } & Motivasi rendah & Esensi motivasi tinggi \\
\hline & Faktor kebiasaan & $\begin{array}{l}\text { Aturan-aturan yang } \\
\text { kuat }\end{array}$ \\
\hline \multirow[t]{4}{*}{$\begin{array}{l}\text { Benda/objek/ } \\
\text { ruang }\end{array}$} & $\begin{array}{l}\text { Tempat } \\
\text { penampungan }\end{array}$ & $\begin{array}{l}\text { Tempat penampungan } \\
\text { yang sudah tersedia }\end{array}$ \\
\hline & $\begin{array}{l}\text { khusus belum } \\
\text { tersedia }\end{array}$ & \\
\hline & $\begin{array}{l}\text { Peralatan cukup } \\
\text { memaadai }\end{array}$ & $\begin{array}{l}\text { Peralatan } \\
\text { memadai }\end{array}$ \\
\hline & $\begin{array}{l}\text { RTH yang belum } \\
\text { tercukupi } \\
\text { sebagai barier }\end{array}$ & $\begin{array}{l}\text { RTH memaksakan } \\
\text { pada lahan sempit } \\
\text { didepan rumah }\end{array}$ \\
\hline \multirow[t]{2}{*}{ Informasi } & $\begin{array}{l}\text { Sosialisasi dan } \\
\text { kurang arahan }\end{array}$ & $\begin{array}{l}\text { Sosialisasi sudah } \\
\text { berjalan dengan rutin }\end{array}$ \\
\hline & $\begin{array}{l}\text { Perlu kerjasama } \\
\text { dengan instansi } \\
\text { luar }\end{array}$ & $\begin{array}{ll}\begin{array}{l}\text { Sudah } \\
\text { kerjasama }\end{array} & \text { adanya } \\
\text { pihak luar. } & \\
\end{array}$ \\
\hline $\begin{array}{l}\text { Konteks } \\
\text { Setting }\end{array}$ & Lokasi I & Lokasi II \\
\hline \multirow[t]{2}{*}{$\begin{array}{l}\text { Hubungan / } \\
\text { jaringan }\end{array}$} & $\begin{array}{l}\text { Kurang } \\
\text { terkoodinir } \\
\text { dengan baik }\end{array}$ & $\begin{array}{l}\text { Terkoordinir dengan } \\
\text { baik }\end{array}$ \\
\hline & $\begin{array}{l}\text { Perlu kerjasama } \\
\text { dengan pihak } \\
\text { luar }\end{array}$ & \\
\hline $\begin{array}{l}\text { Kondisi sosial } \\
\text { ekonomi }\end{array}$ & Tercukupi & Tercukupi \\
\hline Gaya Hidup & Sederhana & Sederhana \\
\hline $\begin{array}{l}\text { Cadangan } \\
\text { Sumberdaya }\end{array}$ & $\begin{array}{l}\text { Masih } \\
\text { digali }\end{array}$ & $\begin{array}{l}\text { Dilanjutkan dalam } \\
\text { koridor yang sama }\end{array}$ \\
\hline
\end{tabular}

Berdasarkan tabel 4 beberapa problematika muncul dan salah satunya pengaruh motivasi rendah yang didasari oleh faktor kebiasaan. Masyarakat di Plesungan menganggap biasa fenomena sampah yang ada di dekat permukiman mereka dan menganggap kurangnya RTH bukan menjadi masalah primer. Sedangkan masyarakat di lokasi 2 sudah memiliki keinginan untuk membentuk komunitas yang didasari atas rasa keprihatinan akan sampah. Masyarakat lokasi 2 memulai dari komunitas kecil membiasakan sosialisasi dan salah satunya menanam tanaman di lahan yang sempit dengan berbagai jenis tanaman.

Disisi lain RTH merupakan poin penting dan sebagai salah satu barrier untuk mencegah dan meminimalkan bau dan asap yang dibawa oleh angin pada saat kemarau kedalam permukiman di lokasi 1. Sedangkan pada lokasi 2 karena lahan mereka sempit akan lebih baik jika menggunakan sistem vertical garden untuk apotik hidup. Keduanya bertujuan untuk menggali lebih terkait sumber daya yang ada pada kedua lokasi untuk bertahan hidup.

Upaya menuju lingkungan yang sehat pada lokasi penelitian dan luaran pada aspek arsitektural maka dapat disimpulkan dan perlunya saran, arahan atau informasi, sebagai berikut:

1. Pengetahuan mengenai lingkungan oleh masyarakat pada lokasi 1 sebenarnya sudah ada, namun pada lokasi radius kurang dari satu kilo meter. Kepercayaan masyarakat sudah menjadi kebiasaan dan menjadi faktor yang kuat. Mereka hidup dengan kondisi apa adanya dalam konteks dekat dengan sumber sampah dan melangsungkan kehidupannya selama bertahuntahun. Seharusnya dalam mempertahankan hidupnya dan meminimalisir dampak buruk, fungsi RTH sangat berperan besar dimana komponen alam tersebut sebagai barrier antara TPA dan permukiman (lokasi 1) dan harus dimaksimalkan serta penambahan ruang publik yang difungsikan sebagai kegiatan sosial dan wadah interaksi antar warga.

2. Tindakan dan gerakan dari suatu komunitas sangat berpengaruh, terutama terhadap pertanggungjawaban pemeliharaan lingkungan. Pada komparasi kedua wilayah ini, dapat diketahui bahwa arahan atau sosialisasi dari pihak atau instansi luar sangat mendukung untuk program kehidupan berkelanjutan dalam perbaikan lingkungan hidup baik dari segi radius lokasi yang berdekatan memungkinkan untuk sulit diperbaiki dan memerlukan penanganan khusus. Sehingga pada lokasi pertama (Kelurahan Plesungan) perlu mendapat arahan dari pihakpihak terkait dan perlu mencontoh pada lokasi kedua. Dengan begitu pengembangan sumber daya manusia akan menjadi lebih maju dan 
terarah serta perbaikan kualitas lingkungan juga akan maju karena pada lokasi kedua terdapat orang-orang yang berkesinambungan untuk memimpin dan mengajak penghuni lain untuk saling mengikat dan menciptakan suatu komunitas bersama. Hal tersebut memicu untuk menciptakan motivasi yang tinggi pada setiap warganya.

3. Kedua sampel lokasi yang menjadi objek pengamatan cukup baik ditinjau dari segi kondisi atau eksisting kampung. Secara tipologi rumah, merupakan jenis rumah layak huni dan sudah terdapat toilet di masing-masing rumah. Dalam hal kumuh atau tidaknya, kedua lokasi tidak memperlihatkan perkampungan kumuh, hanya saja komparasi mengenai kodisi perkampungan, sudah terdapat salah satu lokasi yang melakukan gerakan untuk merapikan eksisting kampung seperti menanam tanaman, mengecat jalan, memberikan tong sampah di setiap rumah yang berangkat dari norma personal masyarakat. Kegiatan mengecat jalan sangat berpengaruh besar terdapat pertumbuhan psikologi anak serta masyarakat muda dan tua dalam hal bersosialisasi dan menciptakan ruang interaksi bersama.

Selanjutnya akan dipaparkan kesimpulan sebagai komparasi kedua wilayah pada tipologi massa bangunan dan aspek arsitektural:

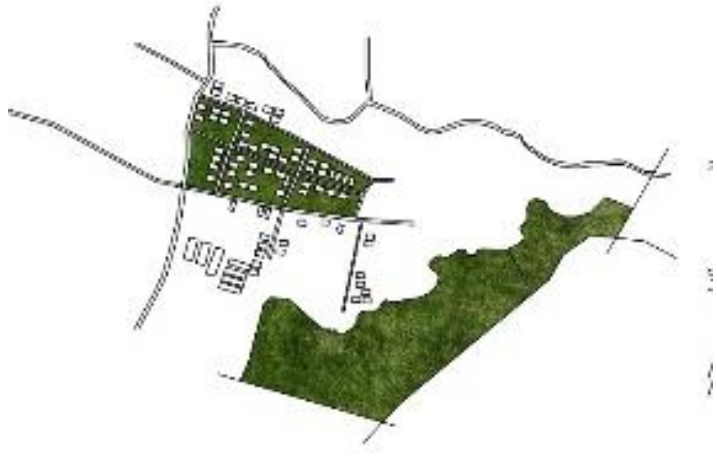

Gambar 4. Illustrasi Tipologi Massa Bangunan Lokasi 1 (Kelurahan Plesungan TPA Putri Cempo) (sumber: Analisis Penulis, 2019)

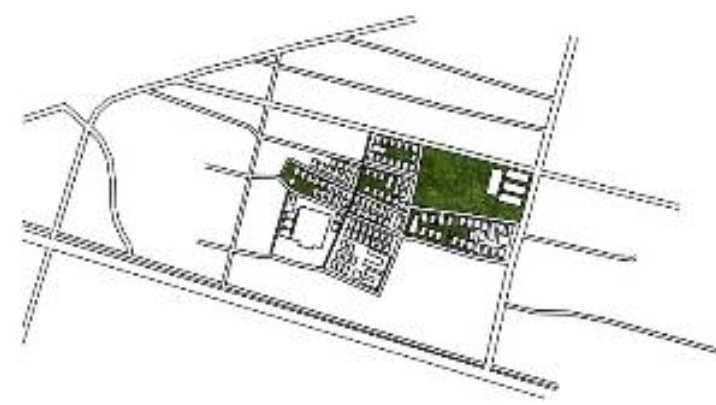

Gambar 5. Illustrasi Tipologi Massa Bangunan Lokasi 2 (Kampung Kitiran Yosoroto) (sumber: Analisis Penulis, 2019)
Pada gambar 4 dan gambar 5 disajikan tipologi tapak dari lokasi 1 dan 2 Berdasarkan analisa tapak terdapat perbedaan antara kepadatan penduduk. Pada lokasi 1 tipologi massa bangunan cenderung jarang/tidak padat sedangkan pada lokasi 2 tipologi bangunannya cukup padat, hal tersebut sangat berpengaruh pada kondisi lingkungan, kekayaan alam dan penduduk sebagai komponen utama dari ekologi manusia, sehingga kekayaan alam harus dapat diambil dan dimanfaatkan untuk mencukupi kebutuhannya dan strategi bertahan hidup.

Sebagai alat untuk memudahkan dalam memahami maksud penelitian, berikut dipaparkan skematik hubungan antara lingkungan sosial dan lingkungan fisik serta alur skematik proses penyelesaian sampah di kedua lokasi penelitian pada gambar 7.

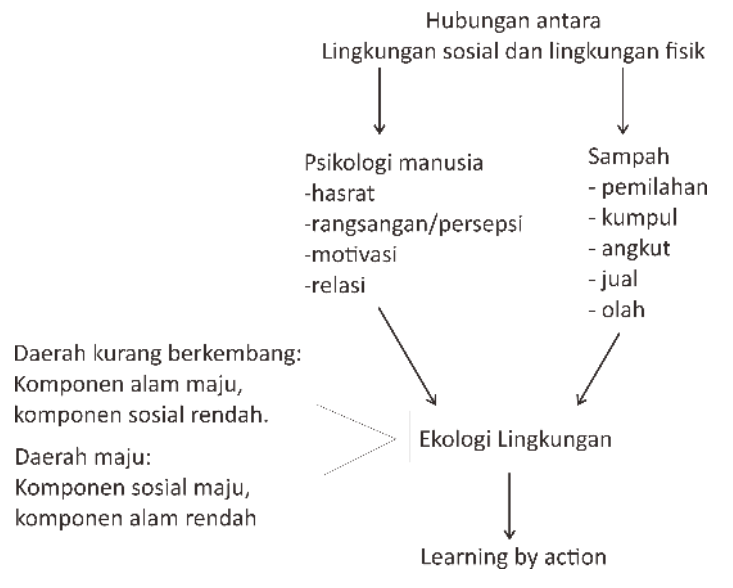

Gambar 7. Skematik hubungan lingkungan sosial dan lingkungan fisik

(sumber: Analisis Penulis, 2019)

Kemudian dipaparkan mengenai alur skematik proses penyelesaian sampah di masing-masing lokasi, pada gambar 8 dan 9 .

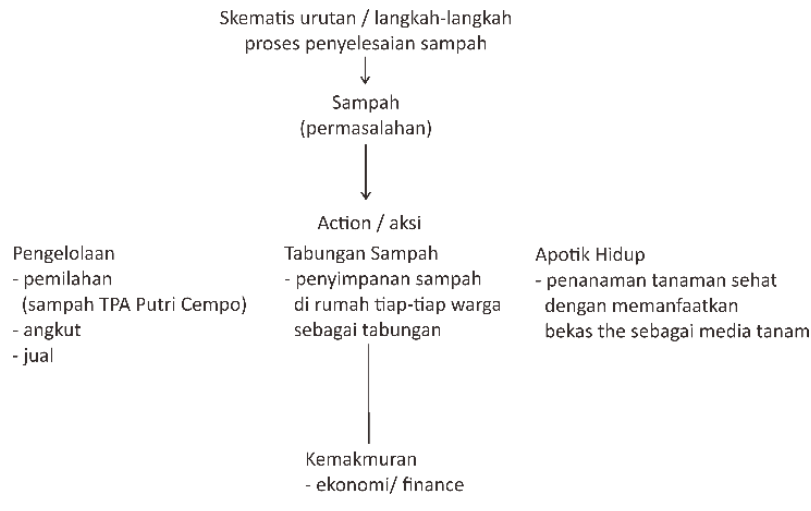

Gambar 8. Alur proses penyelesaian sampah di lokasi 1 (Kelurahan Plesungan TPA Putri Cempo) (sumber: Analisis Penulis, 2019) 


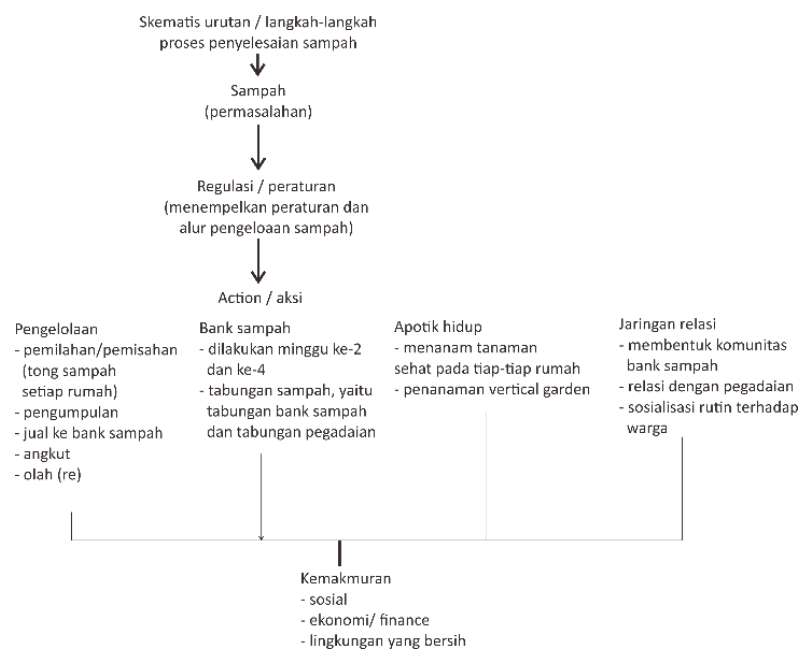

Gambar 9. Alur proses penyelesaian sampah di lokasi 2 (Kampung Kitiran Yosoroto)

(sumber: Analisis Penulis, 2019)

Dalam pencapaian pertanggungjawaban yang sudah dipaparkan, berikut kesimpulan alur dari target proses liability pada gambar 10 .

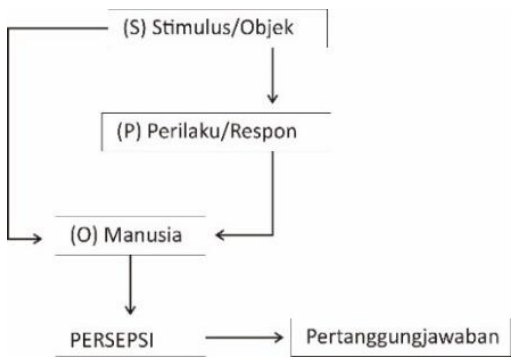

Gambar 10. Alur target pencapaian pertanggungjawaban (sumber: Analisis Penulis, 2019)

Pada saat $(\mathrm{S})-(\mathrm{P})$ berinteraksi, bahwasannya $(\mathrm{S})$ Stimulus/objek memunculkan (P) Perilaku/respon, kemudian (O) pemegang peranan penting dalam hubungan (S)-(P) dan mengambil alih. (S) merupakan objek-objek atau benda yang ada di lingkungan dalam kasus ini adalah sampah, pepohon, tanaman, tanah, dan sebagainya. Sedangkan (P) Pelaku/respon merupakan tindakan atau kebiasaan dari perilaku. Sebagaimana hubungan antara S-P-O menjelaskan sebab-akibat terjadinya suatu tindakan yang memunculkan persepi kedalam pertanggungjawaban.

\section{KESIMPULAN DAN SARAN}

\section{Kesimpulan}

Melalui illustrasi gambar 11 dapat disimpulkan, bahwa hubungan keterkaitan antara komponen alam dan sosial sangat terintegrasi dan berkaitan untuk menentukan kelangsungan hidup manusia (masyarakat). Lingkungan alam meliputi tanah, air, tanaman dan kekayaan alam di dalamnya, sedangkan komponen sosial meliputi unsur pokok yaitu manusia, kelompok masyarakat dan hubungan relasi-organisasi. Hubungan timbal balik kedua komponen tersebut akan memberikan hasil bagi pengguna yang bertanggungjawab dan alam yang terpelihara.

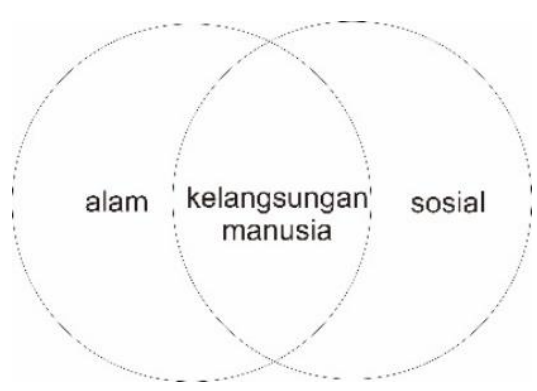

Gambar 11. Hubungan Keterkaitan Ekologi Manusia (sumber: Analisis Penulis, 2019)

1. Lokasi 1 (daerah yang kurang berkembang): Komponen yang paling berpengaruh adalah alam, seperti pada aspek arsitektural yaitu perancangan dan pengelolaan RTH, pemakaian fungsi ruang public dan menggali potensi alam lainnya. Bentuk pertanggungjawaban utama adalah pengelolaan sampah yang baik untuk dampak yang baik pula bagi permukimannya. Lokasi 1 perlu mencontoh pada lokasi 2 terkait pola perilaku yang mereka lakukan seperti pembentukan komunitas, strategi pengelolaan, sampai penanaman berbagai jenis tanaman untuk memakmurkan kehidupan mereka. Di daerah yang kurang berkembang, komponen sosial tidak banyak berperan karena salah satu faktor kesadaran sosialisasi dan hubungan relasi yang kurang. Meskipun daya dukung alam cukup baik namun hal tersebut belum menggambarkan kemakmuran suatu wilayah. Persoalan yang dapat diselesaikan melalui ilmu pengetahuan perlu digali kembali untuk menciptakan kenyaman hidup dan pengelolaan komponen alam yang lebih baik.

2. Lokasi $\mathbf{2}$ (Daerah maju): Komponen yang paling berpengaruh adalah komponen social. Di daerah yang lebih maju masyarakat lebih menggunakan ilmu pengetahuan untuk melaksanakan gerakan terkait perbaikan sumber daya. Meskipun sumber daya alam mereka rendah dan masyarakat maju tidak terlalu bergantung pada kekayaan alam. Pada lokasi 2 sangat minim RTH, namun masyarakat pada lokasi 2 memanfaatkan vertical garden dan penanaman apotik hidup serta membuat relasi kepada masyarakat luas untuk mempertanggungjawabkan dan menunjang kehidupannya. Salah satunya merencanakan, merintis, dan memperluas 
konsep desa wisata yang berbasis edukasi berdasar eksistensi sampah di lokasi tersebut.

Pertanggungjawaban utama dalam ekologi manusia pada kasus penelitian ini yaitu keberhasilan dalam memakmurkan kehidupan. Tokoh manusia yang berperan sebagai komponen primer yaitu mampu mengkombinasikan alam dan manusia dengan menghasilkan lingkungan yang baik seperti menciptakan penghijauan, hubungan sosial, strategi untuk mengatasi krisis seputar environtment di titik mikro-makro pada tapak penelitian.

\section{Saran}

1. Menumbuhkan faktor motivasi dari dalam diri manusia sebagai langkah awal dalam memperbaiki sumber daya dan kelangsungan dalam kehidupan berkelanjutan dengan cara membuat sebuah komunitas.

2. Membuka dan memperluas relasi kepada pihak luar dalam menangani masalah lingkungan hidup.

3. Memperluas pengetahuan mengenai pertanggungjawaban dalam kehidupan bermasyarakat, seperti mengikuti sosialisasi, diskusi, dan studi banding dalam hal ini konteks sampah yang menjadi tolak ukur.

4. Menciptakan solusi arsitektur yaitu RTH dan penghijauan sebagai salah satu barrier dan penghubung antara manusia dan alam.

5. Mengembangkan kawasan yang berkonsep ekowisata untuk memperkenalkan pentingnya lingkungan sehat kepada masyarakat.

\section{DAFTAR PUSTAKA}

Ahmad, Taufiq, "Upaya Pemeliharaan Lingkungan Oleh Masyarakat Di Kampung Sukadaya Kabupaten Subang". Jurnal Geografi Gea, Vol 14 No 2, hal. 124-134. 2014.

Helmi, Avin Fadilla. "Beberapa Teori

Psikologi Lingkungan". Buletin Psikologi. Vol 7, No 2. Hal 7-19. 1999.

Nopyandri, S.H., LL.M. "Hak Atas Lingkungan Hidup Dan Kaitannya Dengan Peran Serta Dalam Pengelolaan Lingkungan Hidup Dalam Perspektif Otonomi Daerah". Jurnal Inovatif, Vol VII No III , hal. 33-44. 2014.

Purwantiasning, Kutipan dalam Jurnal Dedi Hantono, Diananta Pramitasari "Aspek Perilaku Manusia Sebagai Makhluk Individu Dan Sosial Pada Ruang Terbuka Publik". National Academic Jurnal of Architecture. Hal 85-93. 2017

Sukmana , Oman . Dasar-dasar Psikologi Lingkungan. Malang: Bayu Media, 2003.
Veitch, R. \& Arkkelin, D. Environmental Psychology: An Interdisciplinary Perspective. New York: Pearson, 1995.

Wibowo, Istiqomah. "Pola Perilaku Kebersihan: Studi Psikologi Lingkungan Tentang Penanggulangan Sampah Perkotaan". Makara, Sosial Humaniora, Vol 13 No 1, Hal. 37-47. 2009

Undang-Undang Republik Indonesia Nomor 32 Tahun 2009 Tentang Perlindungan Dan Pengelolaan Lingkungan Hidup

Khanza Savitra . 6 Teori Psikologi Lingkungan,(online) https://dosenpsikologi.com/teori-dalampsikologi-lingkungan (diakses November 2019) 